\section{The financial crisis and health care systems in Europe: universal care under threat? Trends in health sector reforms in Germany, the United Kingdom, and Spain}

\author{
Crise financeira europeia e sistemas de saúde: \\ universalidade ameaçada? Tendências das reformas \\ de saúde na Alemanha, Reino Unido e Espanha
}

\author{
Crisis financiera y sistemas de salud europeos: \\ ¿universalidad amenazada? Tendencias de las \\ reformas de salud en Alemania, Reino Unido y \\ España
}

\author{
${ }^{1}$ Escola Nacional de Saúde \\ Pública Sergio Arouca, \\ Fundação Oswaldo Cruz, \\ Rio de Janeiro, Brasil. \\ 2 Fachbereich Pflege \& \\ Gesundheit Hochschule \\ Fulda, Fulda, Germany. \\ Correspondence \\ L. Giovanella \\ Departamento de \\ Administração e \\ Planejamento em Saúde, \\ Escola Nacional de Saúd \\ Pública Sergio Arouca, \\ Fundação Oswaldo Cruz. \\ Av. Brasil 4036, sala 1001, \\ Rio de Janeiro, RJ 21040-361, \\ Brasil. \\ giovanel@ensp.fiocruz.br
}

\begin{abstract}
The paper analyzes trends in contemporary health sector reforms in three European countries with Bismarckian and Beveridgean models of national health systems within the context of strong financial pressure resulting from the economic crisis (2008-date), and proceeds to discuss the implications for universal care. The authors examine recent health system reforms in Spain, Germany, and the United Kingdom. Health systems are described using a matrix to compare state intervention in financing, regulation, organization, and services delivery. The reforms' impacts on universal care are examined in three dimensions: breadth of population coverage, depth of the services package, and height of coverage by public financing. Models of health protection, institutionality, stakeholder constellations, and differing positions in the European economy are factors that condition the repercussions of restrictive policies that have undermined universality to different degrees in the three dimensions specified above and have extended policies for regulated competition as well as commercialization in health care systems.
\end{abstract}

Universal Access to Health Care Services; Health Care Reform; Health Policy
Lígia Giovanella 1

Klaus Stegmüller 2

O artigo analisa tendências de reformas de saúde contemporâneas, em contexto de forte pressão financeira, resultante da crise econômica iniciada em 2008, em países europeus com sistemas nacionais de saúde (modelos bismarckiano e beveridgiano) e discute suas consequências para a universalidade. São analisadas reformas recentes na Espanha, Alemanha e Inglaterra. Para descrição dos sistemas de saúde, utiliza-se matriz comparativa da intervenção estatal no financiamento, regulação, organização e prestação de serviços. $O$ exame das repercussões das reformas sobre a universalidade é realizado com base em três dimensões: amplitude da cobertura populacional; abrangência da cesta de serviços; nível de cobertura por financiamento público. Modelos de proteção em saúde, institucionalidade, constelação de atores e posição na economia europeia diferenciados condicionaram as repercussões das políticas restritivas. Elas afetaram a universalidade nas três dimensões, com distinta intensidade nos países, $e$ aprofundaram políticas prévias de competição regulada e comercialização.

Acesso Universal a Serviços de Saúde; Reforma dos Serviços de Saúde; Política de Saúde 
Immersed in their worst economic crisis since World War II (comparable to that of the 1930s) 1,2, European Union member countries are suffering major financial pressures on their universal health systems. Following the international banking crisis of 2008 triggered in the United States (and resulting from deregulation of the financial market in recent decades), the financial crisis sparked a widespread recession in 2009. Since then, Europe has suffered a crisis with heavy indebtedness and public deficits resulting from government takeover of private bank debts, rising and spreading interest rates in the different European states, and fiscal austerity measures 2,3. European governments used public funds to bail out their financial systems, transferring private bank debts to the public debt, even while the economic recession (with rising unemployment) caused a drop in government revenues 2,4 . This process led to deficits in public budgets and the so-called "public debt crisis".

With the aim of stabilizing the European financial system, a fiscal pact and financial stabilization fund were negotiated to support the countries in crisis. Under the fiscal austerity pact, European Union member countries committed to a sustained reduction in their deficits and greater budget discipline to "consolidate" their public budgets 1,2 . Drawing loans from the stabilization fund, the countries submitted to an austerity and adjustment program that included measures to restructure the labor market and their financial, fiscal, social security, and health systems, along with unprecedented budget cuts in various social programs 3,5. During this process, international agencies have intervened directly in national health policies 6 .

The current article aims to analyze trends in the contemporary health system reforms in a context of heavy financial pressures stemming from the economic crisis (2008-date) in European countries with universal health systems (Bismarckian and Beveridgean models) and to discuss their immediate and potential consequences for universal coverage. We analyze the recent reforms and principal characteristics of the health systems in Spain, Germany, and England.

The crisis affects the European countries to different degrees and in different ways, depending on each country's capitalist development model and corresponding welfare state regime, with distinct interactions between growth policies, labor market institutions, and social sectors 2 , the correlation of political forces, and countries' differential insertion in the single European market. However, by taking excessive public indebtedness resulting from the banking crisis as the cause of the crisis, the single recipe of the European agencies is a fiscal austerity program that affects social policies and impacts health reforms 5 .

European health systems are already showing repercussions from the economic crisis and fiscal austerity policies. In 2010, in various European countries, real per capita health expenditures decreased, reversing a persistently upward trend (4.6\% per year in the previous decade) 7,8 . The economic crisis also impacts access to health services and the population's health status, with an increase in suicides, homicides, mental disorders, and drug abuse in the most heavily affected countries $9,10,11$.

\section{Methodology}

Comparative analysis of countries is a traditional approach in political science that has been widely used for some time to study regimes and institutions. In the social policy field, it allowed identifying welfare state regimes, as in the classical studies by Titmuss 12 and Esping-Andersen 13. In public policies, it is common to compare structures and institutions for operational purposes and (more recently) to identify performance determinants 14 .

In health, comparative policy analysis has evolved in recent decades, moving away from simple performance classifications and ranking of health systems between countries, viewed with increasing skepticism 15 , towards studies aimed at a more in-depth understanding of the conditions under which given changes occur: what works, where, and why 16.

Case studies are still the cornerstone of comparative research, and the trend among comparative scholars is intensive analysis of a few cases, since it allows a comprehensive understanding of the theme under study and the multiple interrelations between the observed phenomena 14,17 . In health policies, the best comparative studies analyze a few cases and examine a specific theme based on a common structure or matrix, and/or a main theoretical question 18 .

For the current study, three cases were selected that exemplify European countries with universal health systems: Germany, Spain, and the United Kingdom. These countries differ in their welfare systems and in the organization of their health care systems, and are subject to different financial pressures from the European crisis. During the pre-crisis period, they were similar in their high economic and social development with an expanded social protection system, universal health coverage with public financing, and 
public financing exceeding $75 \%$ of total health expenditures. The three countries share excellent health indicators and an analogous epidemiological situation and face similar demographic pressures and prevalence rates for chronic diseases (Table 1).

The selected cases allow comparing reforms in the face of the crisis and trends in countries with distinct modalities of health protection and health system organization. The study assumes that differences in health sector institutionality and the countries' positions in the European financial crisis condition the impacts on their respective health systems 18 .

As a tool for comparison and analytical description of the health systems, a matrix was developed that contemplates the dimensions of state intervention in health as suggested by Immergut 19 and the corresponding categories: financing (share of different sources of financing, trends in public financing, copayment, modalities of resource allocation); regulation (insurance, services package and incorporation of medical technologies, relations between financers and providers, payment systems); and health services organization and delivery, grouping ownership of services and health employment (supply and organization of primary outpatient and specialized care, hospital care, share and role of public and private providers, management modalities, employment modalities, changes in public-private relations in the delivery of services).

The analysis of how health system reforms impacted universal coverage was based on the model proposed by the World Health Organization (WHO) 20, including three dimensions of universal coverage: (i) breadth of population coverage by social health protection (variations in the insured population and rules for inclusion); (ii) depth of the package of services (changes in the package, rationing measures, variation in supply); and (iii) height of coverage by public financing (proportion of health spending covered publicly, trends in public expenditures, and changes in copayment).

The sources of information and techniques included: document analysis of reforms and legislative bills (2008-2012), secondary data from the Organization for Economic Cooperation and Development (OECD) Health Data, and statistics from the European Union and individual countries' information systems. A review of the recent literature was performed to monitor the current reform processes, including the gray literature and press articles, since they examine processes under way, without the delay involved in publishing analytical articles in scientific journals. They provide valuable additional sources of in- formation for analyzing contemporary political processes 21 .

\section{National health systems from a comparative perspective}

Germany, England, and Spain have different welfare regimes 13,22, and in health they represent two main modalities of state intervention: Bismarckian social insurance and Beveridgean national health service models (Table 1).

In Germany, social health protection is guaranteed by compulsory Social Health Insurance, depending on participation in the labor market and solidarity contributions by workers and employers in proportion to wages 23 and currently covering $89 \%$ of the population. In the United Kingdom, the National Health Service (NHS), created in 1948, with universal access based on citizenship and tax-based financing, guarantees free coverage to the entire population, using a traditionally single and centralized structure. However, the NHS-UK was decentralized in 2004 to the four countries of the United Kingdom, and the current NHS of England, Scotland, Wales, and Northern Ireland display some distinct characteristics 24 . Therefore, the case analyzed in this article is NHS-England. In Spain, after a prolonged dictatorship, the 1978 Constitution provided the universal right to health care, and 1986 witnessed the creation of the Sistema Nacional de Salud, or National Health System (SNS), with tax-based financing and universal access, decentralized to the 17 Autonomous Communities (State level) 25,26,27.

\section{Financing}

Financing is predominantly public, with distinct sources and characteristics in the three countries, summarized in Table 2. Resource allocation displays different dynamics. In Germany, a Health Fund of the Gesetzliche Krankenversicherung (GKV), created in 2009, combines all the contributions collected by the Sickness Funds and redistributes them on a risk-adjusted per capita basis using age, gender, and presence of 80 diseases among the insured population in each Fund 28. Allocation between sectors results from negotiations between Sickness Funds and organizations representing providers according to sector of care.

In Spain, the responsibility for health care has been fully transferred to the Autonomous Communities (CCAA) since 2002, and health care financing has been integrated into general 
Table 1

General characteristics of selected case countries: Germany, Spain, and United Kingdom.

\begin{tabular}{|c|c|c|c|}
\hline Countries & Germany & Spain & United Kingdom \\
\hline Capitalist model & $\begin{array}{l}\text { Coordinated market economy or } \\
\text { "social market economy". }\end{array}$ & $\begin{array}{l}\text { Coordinated market economy, in } \\
\text { transition to liberal model. }\end{array}$ & Liberal market economy. \\
\hline Welfare state regime 22 & $\begin{array}{l}\text { Corporatist conservative/merit-based } \\
\text { regime. } \\
\text { Less de-commodification and greater } \\
\text { family participation than in the Social- } \\
\text { Democratic model. } \\
\text { Based on social insurance with } \\
\text { right to access conditioned on } \\
\text { participation in the labor market, } \\
\text { previous contribution, and } \\
\text { equivalence between contributions } \\
\text { and benefits with maintenance of } \\
\text { differential statuses. }\end{array}$ & $\begin{array}{l}\text { Post-dictatorial regime. } \\
\text { Recent tradition of government } \\
\text { intervention in social services, } \\
\text { fragmentation, strong family } \\
\text { influence, lower social benefits } \\
\text { in comparison to other European } \\
\text { countries, participation by private } \\
\text { sector, Catholic tradition, and } \\
\text { permanence of patrimonialist } \\
\text { relations. }\end{array}$ & $\begin{array}{c}\text { Residual liberal regime. } \\
\text { Low de-commodification, reduced } \\
\text { income redistribution, focus on } \\
\text { poverty relief, and access to benefits } \\
\text { by means tests. } \\
\text { Exception: NHS, with universal } \\
\text { access. }\end{array}$ \\
\hline $\begin{array}{l}\text { Social health protection } \\
\text { model }\end{array}$ & $\begin{array}{l}\text { Statutory health insurance financed } \\
\text { with mandatory social contributions } \\
\text { proportional to wages with no } \\
\text { relationship to risk. } \\
\text { Established in } 1883 .\end{array}$ & $\begin{array}{l}\text { National health service with universal } \\
\text { access and tax-based financing. } \\
\text { Established in } 1986 .\end{array}$ & $\begin{array}{c}\text { National health service with universal } \\
\text { access and tax-based financing. } \\
\text { Established in } 194824 .\end{array}$ \\
\hline $\begin{array}{l}\text { Year of entry into the } \\
\text { European Union }\end{array}$ & 1951 & 1986 & 1973 \\
\hline $\begin{array}{l}\text { Parties/coalition in power } \\
\text { in } 2000 \text { s }\end{array}$ & $\begin{array}{l}\text { 1998-2005: Social-Democrat/Green. } \\
\text { 2005-2009: grand coalition (Christian } \\
\text { Democratic-Social Democratic). } \\
\text { 2009: Conservative/Liberal. }\end{array}$ & $\begin{array}{l}\text { 1996-2004: Conservative (PP). } \\
\text { 2004-2011: Social Democratic } \\
\text { (PSOE). } \\
\text { 2011: Conservative (PP). }\end{array}$ & $\begin{array}{l}\text { 1997-2010: Social Democratic/New } \\
\text { Labor } \\
\text { 2010: Conservative Liberal. }\end{array}$ \\
\hline $\begin{array}{l}\text { Per capita GDP in ppp US } \$ \\
(2010)^{*}\end{array}$ & 37,567 & 32,076 & 35,917 \\
\hline $\begin{array}{l}\text { Population in millions } \\
(2010) *\end{array}$ & 82.805 & 45.289 & 64.757 \\
\hline $\begin{array}{l}\text { Percentage of population } \geq \\
65 \text { years * }\end{array}$ & 20.4 & 17.0 & 16.0 \\
\hline $\begin{array}{l}\text { Life expectancy at birth } \\
(2010)^{*}\end{array}$ & 80.5 & 82.2 & 80.6 \\
\hline Men & 78.0 & 79.1 & 78.6 \\
\hline Women & 83.0 & 85.3 & 81.1 \\
\hline Infant mortality (2010) * & 3.4 & 3.2 & 6.1 \\
\hline $\begin{array}{l}\text { Maternal mortality/100,000 } \\
\text { live births }(2010) \star \star\end{array}$ & 5.5 & 4.1 & 5.0 \\
\hline $\begin{array}{l}\text { Three leading causes of } \\
\text { death \% (2009) }\end{array}$ & $\begin{array}{l}\text { 1st: cardiovascular diseases (41.7\%) } \\
\text { 2nd: cancer (26.0\%) } \\
\text { 3rd: respiratory diseases (7.4\%) }\end{array}$ & $\begin{array}{l}\text { 1st: cardiovascular diseases (31.7\%) } \\
\text { 2nd: cancer (26.9\%) } \\
\text { 3rd: respiratory diseases (11.4\%) }\end{array}$ & $\begin{array}{l}\text { 1st: cardiovascular diseases (32.5\%) } \\
\text { 2nd: cancer (28.0\%) } \\
\text { 3rd: respiratory diseases (13.8\%) }\end{array}$ \\
\hline $\begin{array}{l}\text { Stroke mortality in } \\
\text { men/100,000 (2010) } 8\end{array}$ & 38 & 38 & 43 \\
\hline $\begin{array}{l}\text { Breast cancer mortality in } \\
\text { women/100,000 (2010) } 8\end{array}$ & 24.0 & 17.7 & 24.5 \\
\hline
\end{tabular}

* Organisation for Economic Co-operation and Development. Country statistical profiles 2012. http://www.oecd-ilibrary.org/economics/country-statisticalprofiles-key-tables-from-oecd_20752288 (accessed on 04/Feb/2013);

** Organisation for Economic Co-operation and Development. StatExtract: 2013. http://stats.oecd.org/index.aspx?DataSetCode=HEALTH_STAT\# (accessed on 04/Feb/2013). 
Table 2

Financing of national health systems in Germany, Spain, and England.

Characteristics
Gesetzliche Krankenversicherung

(GKV) Statutory Health Insurance

Public spending on health

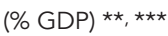

2005

2008

2010

2011

Public spending on health

(\% of total expenditure) **

2000

2005

2010

2011

Per capita public spending on health in ppp US\$ **

2000

2005

2008

2009

2010

Total health spending

$(\% \mathrm{GDP}) * *, * * *$

2000

2005

2010

Financing model

Principal sources/agents

(2010) 24,28 **

Fiscal resources

Social security contributions

Private insurance

Out-of-pocket

Copayment in public system/ social insurance

8.0
7.9
8.6
8.4

\section{6}

6.3

6.9

6.6

79.5

76.6

76.7

76.5

2,130

2,577

3,037

3,250

3,331

10.4

10.8

11.6

Social contributions, proportional to wages (15.5\%) unrelated to risk:

$8.2 \%$ workers;

$7.3 \%$ employers.

7.2

8.3

9.6
71.6

71.0

74.2

73.0

1,101

1,614

2,169

2,314

2,267

Fiscal resources decentralized to CCAA (progressive taxation).

69.2

4.6

5.7

20.2

10 Euros per day for hospitalization, maximum 28 days; medicines, health transportation, and other means from 5 to 10 Euros; maximum burden $2 \%$ of family income and $1 \%$ for chronic patients; partial subsidies for dental prostheses; Exempt: children up to 18 years and pregnant women.
United Kingdom/England *

National Health Service (NHS) 
Table 2 (continued)

\begin{tabular}{|c|c|c|c|}
\hline Characteristics & $\begin{array}{l}\text { Germany } \\
\text { Gesetzliche Krankenversicherung } \\
\text { (GKV) Statutory Health Insurance }\end{array}$ & $\begin{array}{c}\text { Spain } \\
\text { Sistema Nacional de Salud (SNS) }\end{array}$ & $\begin{array}{l}\text { United Kingdom/England * } \\
\text { National Health Service (NHS) }\end{array}$ \\
\hline $\begin{array}{l}\text { Financial transfers/ Resource } \\
\text { allocation }\end{array}$ & $\begin{array}{l}\text { A Social Health Insurance Fund } \\
\text { combines the levied social } \\
\text { contributions and redistributes } \\
\text { them among the GKV Sickness } \\
\text { Funds on a per capita member } \\
\text { basis, weighted by age, gender, } \\
\text { and illness } \\
\text { ( } 80 \text { health conditions). } \\
\text { Allocation between sectors: annual } \\
\text { negotiations between corporate } \\
\text { stakeholders by sector of care. }\end{array}$ & $\begin{array}{l}\text { Health resources part of overall } \\
\text { transfers to CCAA, non-binding, } \\
\text { structured in Essential Public } \\
\text { Services Guarantee Fund and } \\
\text { Global Sufficiency Fund. }\end{array}$ & $\begin{array}{l}\text { Transfer to CCGs, previously } \\
\text { PCTs, by weighted capitation: per } \\
\text { capita adjusted by demographic, } \\
\text { epidemiological, socioeconomic, } \\
\text { and health inequality factors. }\end{array}$ \\
\hline
\end{tabular}

CCAA: Autonomous Communities; CCGs: clinical commissioning groups; PCTs: primary care trust; GDP: Gross Domestic Product.

* Numerical data refer to the United Kingdom and to the specifications of NHS-England;

** Organisation for Economic Co-operation and Development. Country statistical profiles 2012. http://www.oecd-ilibrary.org/economics/country-statisticalprofiles-key-tables-from-oecd_20752288 (accessed on 04/Feb/2013);

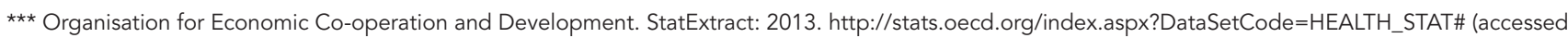
on 04/Feb/2013).

non-binding Federal transfers, calculated on the basis of demographic criteria and public services to be covered 29 .

In England, transfers to the decentralized agencies of the NHS responsible for hiring services (health authorities, subsequently "primary care trusts" or PCTs, and since 2013 the "clinical commissioning groups" or CCGs), are based on a "weighted capitation" formula for equitable resource allocation: per capita allocation adjusted by demographic, epidemiological, socioeconomic, and health inequality factors (Table 2) 24 .

\section{Regulation}

Market-oriented health reforms in recent decades have posed new challenges for state regulation and have been accompanied by the creation of specific agencies for the task 30 . Regulation of health protection and the health system in the three countries occurs in different ways, in addition to the respective national legislative processes. In Germany, the decisionmaking process is shared among corporate organizations with public functions, the Federal government, and the 16 States. Health sector regulation is traditionally of the meso-corporatist type, according to which the government delegates regulation of a given sector of society to the stakeholders immediately involved in that activity. Federal legislation defines the structural conditions, while the competencies for their materialization are delegated to the stakeholders, namely representative organizations of the Sickness Funds, and providers, especially the Associations of Accredited Phisicians (KVen) and the Joint Federal Commission of Sickness Funds, Physicians, and Hospitals (G-BA) 31 .

In England, the NHS was traditionally regulated by the Department of Health, which both financed the system and regulated resource allocation and delivery. Beginning with the establishment of the internal market in the 1990s, a series of independent agencies with specific regulatory functions were created and successively restructured, featuring the National Institute for Health and Care Excellence (NICE), Monitor, and Care Quality Commission (CQC) (Table 3) 21,30,32.

Regulation of Spain's SNS occurs mainly through national and State legislation and government agencies: Ministry of Health, Inter-Territorial Council of the SNS, and the Consejerias or Boards of Health and Health Services of the 17 Autonomous Communities or CCAA (States). The Federal government, through the Ministry of Health, is responsible for setting basic standards and requirements for the functioning and coordination of the SNS and for guaranteeing equity. The 17 Regional Health Systems organized by the CCAA are autonomous and report to their local parliaments 27 .

In the three countries, the guarantees for entitlement and population coverage are regulated 


\section{Table 3}

Regulatory characteristics of the national health systems in Germany, Spain, and England *

\begin{tabular}{|c|c|c|c|}
\hline \multirow[t]{2}{*}{ Regulation } & Germany & Spain & United Kingdom/England * \\
\hline & $\begin{array}{l}\text { Gesetzliche Krankenversicherung } \\
\text { (GKV) or Statutory Health Insurance }\end{array}$ & Sistema Nacional de Salud (SNS) & National Health Service (NHS) \\
\hline
\end{tabular}

Predominant form of regulation

National legislation and mesocorporatist regulation through organizations with public functions, representing sickness funds and providers.

Population entitlement and coverage 64

Compulsory social insurance linked to participation in the labor market. GKV 146 sickness funds in 2012.

Covers $89 \%$ of the population (2011).

Private insurance

coverage

Package covered

Regulation of package of services and incorporation of technologies

Regulation of the relationship between financers and providers
$11 \%$ substitutive $(4.4 \%$ public employees).

Deep at all levels of care. Includes nearly all available diagnostic and therapeutic measures; sickness compensation; uniform coverage between sickness funds; no predefined package.

Joint Federal Commission of the GKV: corporatist, consisting of representatives of the sickness funds, physicians, and hospitals; supported by the Institute for Quality and Efficiency of the Health System (Institut für Qualität und Wirtschaftlichkeit im

Gesundheitswesen-IQWiG)

Collective (and selective) contracts between sickness funds and corporate organizations of providers in each sector of care: Associations of Accredited Physicians, Associations of Accredited Dentists, associations of hospitals, pharmacies, midwives, pharmaceutical industry, etc.
National and State legislation, and by government agencies: Ministry of Health, Inter-Territorial Council, Consejerias de Salud e Servicios de Salud of the 17 Autonomous Communities.

Universal access for citizens and residents. Coverage of $99 \%$ of the population (2011).

SNS with 17 Community Health Services (State).

$13 \%$ - additive/duplicate (5\% substitutive for public employees)

Deep at all levels of care; a portfolio of common services is defined, to be guaranteed in all the CCAA; limited dental care; variations between CCAA.

Ministry of Health supported by the Inter-Territorial Council of the SNS consisting of the 17 Health Council Members of the CCAA, and prior assessment by the Agency for Health Technology Assessment of the "Carlos III" Institute of Health and the Spanish Network for Health Technology Assessment.

Relationship between the Consejería de Salud (financer) and the Regional Health Service (provider) regulated by a program contract (goals-based management system), reproduced at the various management levels: between the Regional Service and the Area Management Bodies, and between these and their health centers and hospitals.
National legislation and independent specialized agencies: National Institute for Health and Care Excellence (NICE),

Monitor, Care Quality Commission (COC).

Universal access for citizens and habitual residents.

NHS $100 \%$ of the population.

$$
13 \% \text { - additive }
$$

Deep at all levels of care; guaranteed comprehensive care, no predefined package.

NICE recommends clinical guidelines and defines whether new procedures/ treatments should be made available by the NHS based on costeffectiveness analyses. Develops guidelines for the use of technologies; clinical practice guidelines for appropriate treatment of specific diseases; health promotion guidelines.

Service commissioning contracts between PCT/CCG and providers. CQC: sets standards and monitors safety and quality of services.

Monitor: regulates Foundations Trusts, licenses providers, regulates competition between NHS providers (any qualified provider) and sets prices.

CCAA: Autonomous Communities; CCGs: clinical commissioning groups; PCTs: primary care trusts.

* Numerical data refer to the United Kingdom and to the specifications of NHS-England. 
by national legislation, and services coverage is comprehensive at all levels of care. The incorporation of new services and technologies tends to be regulated by specific agencies (Table 3 ).

Relations between financers and providers are regulated by different mechanisms in the three countries. In Germany, relations are regulated corporately by collective bargaining (with some selective contracts) between Sickness Funds and providers, organized representatively in Associations in each of the health care sectors: accredited physicians, accredited dentists, pharmacies, midwives, as well as directly with the pharmaceutical industry.

In England, with the creation of the internal market and separation of roles between financing and delivery in the NHS, primary care organizations took over the planning, commissioning, and service procurement roles and began to establish contracts with providers of specialized care. Such primary care organizations have assumed different formats over time: in the 1990s, some GP-Fundholders; from 2003 to 2012, the PCTs grouped all the GPs (general practitioners) in a given area, and since 2013 the CCGs were created. Relations between CCGs and other providers are currently regulated by the new health authority, NHS-England, which authorizes, hires, and monitors the clinical commissioning groups (CCGs), transfers resources, and commissions primary care services and part of the higher-complexity specialized care, replacing the previous strategic health authorities. CQCs set standards and monitor safety and quality of services. The Monitor licenses providers, sets prices, and regulates competition between NHS providers 24,33 .

In Spain, the health authority in each CCAA is the Consejeria de Salud, responsible for individual and collective health policy by establishing, regulating, and planning the Autonomous/ Regional Health Service, which adopts different management formats in the various CCAA. Its attributions include health services delivery and management and coordination of networks. The relationship between the Consejeria de Salud (financer) and the Autonomous/Regional Health Service (provider) and between the latter and each health area management tier is regulated by a program contract: a goals-oriented management system that defines the budget, an assessment model, and incentives to strengthen strategic lines of action 26 .

\section{Organization and delivery of services}

The state's social protection models and territorial arrangements in each country condition the organization of their health care systems. Germany's Social Health Insurance does not deliver services directly, but contracts them out to public or private providers organized in corporate entities, without regionalization or territorial organization of the network. In the national health services in England (unitary) and Spain (decentralized to the States), the predominant format is the system's own providers with a tradition of regionalized and hierarchical territorial organization of services networks, strong primary care, and general practitioners in the gatekeeper role. Table 4 summarizes the main characteristics of the system's organization and outpatient and hospital care in the three countries.

The three country cases differ as to characteristics of the hospital sector. In Germany, the Sickness Funds establish contracts with each hospital and pay for their users' hospitalizations based on a system of prospective, diagnosis-related payment (adapted DRG). Nearly all of the hospitals in Germany are hired by the all Sickness Funds, with the supply distributed between public (49\%), charity (35\%), and private providers (17\%) 28 .

In the English hospital sector, the establishments are predominantly public (95\%), although they have gradually assumed greater management autonomy (trusts), and the physicians are salaried employees of the NHS 24 .

In Spain, $84 \%$ of the general hospital beds are public and $81 \%$ of hospitalizations are financed by the SNS, of which $92 \%$ provided by public hospitals 34 . Each health area, with a population of 200 to 250 thousand inhabitants, has at least one general hospital in charge of admissions, specialized outpatient care, and emergency services. Most hospitals are still under direct public administration with a program management contract with the CCAA Regional Health Service 26 .

\section{Financial crisis and health reforms}

In recent decades, facing economic, demographic, epidemiological, and political pressures, health systems in European countries have undergone repeated reforms. Particularly in the 1990s, accompanying neoliberal economic policies, widespread reforms were implemented, in troducing market mechanisms to increase competition in public health systems, with different results between countries, conditioned by the institutional legacy, traditions of state interven- 
Organization and provision of services in the national health systems of Germany, Spain, and England.

\begin{tabular}{|c|c|c|c|}
\hline Characteristics & $\begin{array}{l}\text { Germany } \\
\text { Gesetzliche Krankenversicherung } \\
\text { (GKV) Statutory Health Insurance }\end{array}$ & $\begin{array}{c}\text { Spain } \\
\text { Sistema Nacional de Salud (SNS) }\end{array}$ & $\begin{array}{l}\text { United Kingdom/England * } \\
\text { National Health Service (NHS) }\end{array}$ \\
\hline \multicolumn{4}{|l|}{ Outpatient care } \\
\hline $\begin{array}{l}\text { Characteristics of primary } \\
\text { care/type of provider }\end{array}$ & $\begin{array}{l}\text { No definition of first level; self- } \\
\text { employed professionals; private } \\
\text { offices accredited with the GKV } \\
\text { through the Associations of } \\
\text { Accredited Physicians. }\end{array}$ & $\begin{array}{l}\text { Territorial organization in health } \\
\text { areas subdivided in basic zones } \\
\text { with a population of } 5 \text { thousand to } \\
25 \text { thousand registered in public } \\
\text { primary health care centers with full- } \\
\text { timed salaried professionals. }\end{array}$ & $\begin{array}{l}\text { GP clinics, self-employed } \\
\text { professionals with exclusive } \\
\text { contract with NHS; territorial } \\
\text { organization in } 211 \text { CCGs including } \\
\text { GPs from a region responsible for } \\
\text { commissioning secondary services } \\
\text { (since 2013). }\end{array}$ \\
\hline Gatekeeper role & $\begin{array}{l}\text { No (some selective contracts with } \\
\text { voluntary adherence). }\end{array}$ & $\begin{array}{l}\text { Yes: list of } 1,300 \text { to } 1,800 \text { users for } \\
\text { GPs and } 700 \text { children up to } 15 \text { years } \\
\text { for pediatricians. }\end{array}$ & $\begin{array}{l}\text { Yes: average list of 1,432 patients } \\
\text { per GP (2009) (compared to } 1,999 \\
\text { in 1997). }\end{array}$ \\
\hline Primary health care "team" & $\begin{array}{l}\text { No primary care teams are } \\
\text { established; care provided by the } \\
\text { GP; some assistants delegated to } \\
\text { perform home visits in rural areas; } \\
\text { independent midwives. }\end{array}$ & $\begin{array}{l}\text { Multi-professional teams: family and } \\
\text { community physicians, pediatricians, } \\
\text { nurses, support from social workers, } \\
\text { physical therapists, midwives. }\end{array}$ & $\begin{array}{l}\text { On average, clinic with } 5 \mathrm{GPs} \text {, } \\
\text { nurses, physical therapists, health } \\
\text { care assistants, administrators. }\end{array}$ \\
\hline $\begin{array}{l}\text { Form of payment for } \\
\text { primary care }\end{array}$ & $\begin{array}{c}\text { Cases treated per quarter; limited } \\
\text { by financial caps per office and } \\
\text { specialty. }\end{array}$ & $\begin{array}{l}\text { Salary plus per capita complement } \\
\text { per user registered on the list, } \\
\text { adjusted by age (15\%). }\end{array}$ & $\begin{array}{l}\text { Capitation adjusted by risk + } \\
\text { performance. }\end{array}$ \\
\hline $\begin{array}{l}\text { Characteristics of } \\
\text { specialized care } \\
\text { (consultations and } \\
\text { procedures) }\end{array}$ & $\begin{array}{l}\text { Self-employed professionals; private } \\
\text { offices accredited with the GKV } \\
\text { through Associations of Accredited } \\
\text { Physicians. }\end{array}$ & $\begin{array}{l}\text { Access to specialized care, } \\
\text { conditioned on referral by GP, } \\
\text { provided in hospital outpatient } \\
\text { clinics or specialty centers linked to } \\
\text { the Area's public hospital by salaried } \\
\text { specialists of the CCAA. }\end{array}$ & $\begin{array}{l}\text { Access to specialized care, } \\
\text { conditioned on referral by GP, } \\
\text { provided in outpatient clinics } \\
\text { of public hospitals (Trusts and } \\
\text { Foundation Trusts) by salaried } \\
\text { specialist physicians of the NHS. }\end{array}$ \\
\hline 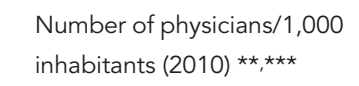 & 3.7 & 3.8 & 2.4 \\
\hline $\begin{array}{l}\text { Number of GP/1,000 } \\
\text { inhabitants (2010) } 24 \#\end{array}$ & 0.7 & 0.8 & 0.7 \\
\hline $\begin{array}{l}\text { Number of medical } \\
\text { consultations/1,000 } \\
\text { inhabitants }(2010) 46 * \star, \star * \star\end{array}$ & 17.0 & 7.5 & 5.0 \\
\hline $\begin{array}{l}\text { Form of payment for } \\
\text { specialized dare }\end{array}$ & $\begin{array}{l}\text { Cases treated per quarter, limited } \\
\text { by financial caps per office and } \\
\text { specialty. }\end{array}$ & $\begin{array}{l}\text { Salary plus complement, differing } \\
\text { between CCAA. }\end{array}$ & $\begin{array}{l}\text { Salary plus complements for } \\
\text { performance. }\end{array}$ \\
\hline \multicolumn{4}{|l|}{ Hospital care } \\
\hline $\begin{array}{l}\text { Number of acute care } \\
\text { beds } / 1,000 \text { inhabitants } \\
(2010) \star \star . \star \star \star\end{array}$ & 5.7 & 2.5 & 2.4 \\
\hline $\begin{array}{l}\text { Distribution of beds per } \\
\text { provider (2010) 24.28.34 \#\# }\end{array}$ & & & \\
\hline Public \% (n) & $48.6(387)$ & $83.9(376)$ & 94.2 \\
\hline Private non-profit \% (n) & 34.5 (229) & - & - \\
\hline Private \% (n) & $16.9(125)$ & $16.1(113)$ & 5.8 \\
\hline
\end{tabular}

(continues) 


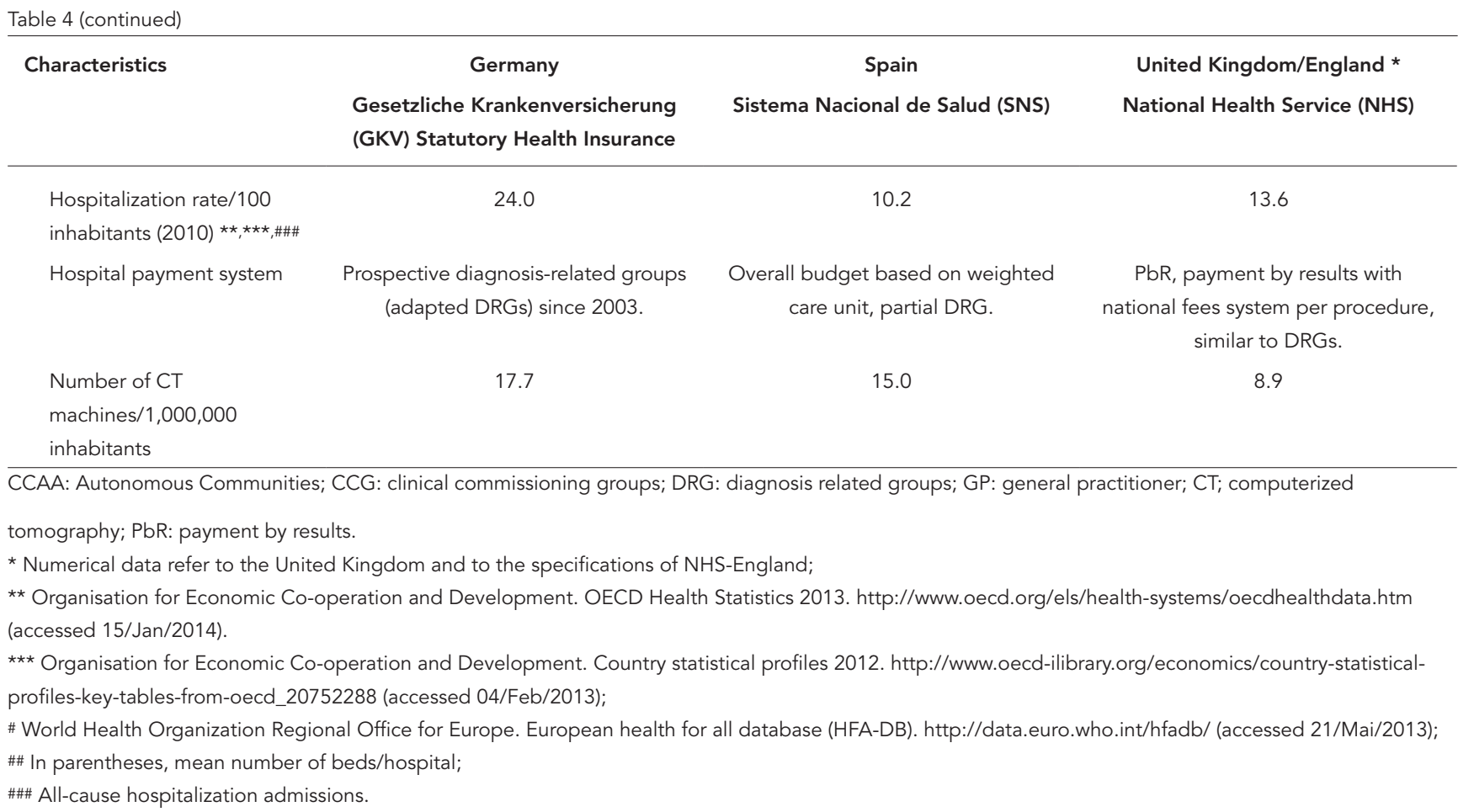

tion in health, stakeholder constellations, power distribution, and values $31,35,36,37$.

In the context of the crisis, the three countries experience distinct financial pressures (Table 5) with different repercussions on the health systems. Spain, UK, and Germany entered a recession in 2009, but their different positions in the European economy conditioned both the ways they dealt with the crisis 38,39 and its consequences for the national health systems, as presented next, beginning with Spain.

Spain was one of the European countries most heavily affected by the 2008 financial crisis. With a production model characterized by low competitiveness, moderate deindustrialization after the country's entry into the European Union, growing economic dependence on the construction market and mortgages, and a real estate boom that led to progressive private indebtedness, the burst in the real estate bubble had disastrous effects: widespread default by indebted families, growing unemployment, and rising interest rates (European Central Bank. Statistical data warehouse 2013. http://sdw.ecb.eu ropa.eu, accessed 13/Jan/2013) 40,41. With the ongoing recession, the public deficit has remained above $10 \%$ since 2009 (Table 5).

In the face of the crisis, Spain submitted to fiscal austerity dictates by imposing major cuts in public expenditures 41 . In health, in 2012, a specific national act called the Royal Decree Law 16/2012 42 included drastic measures: seven billion Euros in cuts in the SNS, a change in entitlement, excluding undocumented immigrants, changes in the common package of services, expanded copayments, and changes in the regulation of pharmaceutical care. Table 6 summarizes the impacts of this reform on universal coverage.

Considered a counter-reform move against the guarantee of a universal public system 26,43,44, $R D L$ 16/2012 42 imposed a legal change in entitlement and thereby broke with the principle of health as a right of citizenship and established Social Security membership as a condition, in opposition to the universal citizen's right and the spirit of the General Health Law of 1986 that created the SNS, in a break with previous consensuses and a return to its Bismarckian origins, according to various researchers that have criticized the reform 26,43,45.

The Conservative government has created a drastic scenario of cuts in the SNS that have already reduced the mean per capita budget in the SNS from 1,343 to 1,203 Euros between 2010 and 2012 46,47,48. The spending reduction was achieved mainly through cuts in staff (wage freezes and cuts, lack of employee replacement, increased workload) and in pharmaceutical care, given increases in copayment and new rules for rational use 47 . As an immediate consequence of 
Economic indicators, Germany, Spain, and United Kingdom, 2008-2012.

\begin{tabular}{|c|c|c|c|}
\hline Economic indicators & Germany & Spain & United Kingdom \\
\hline \multicolumn{4}{|l|}{ Annual growth rate (\% GDP) * } \\
\hline 2008 & 1.1 & 0.9 & -0.8 \\
\hline 2009 & -5.1 & -3.8 & -5.2 \\
\hline 2010 & 4.0 & -0.2 & 1.7 \\
\hline 2011 & 3.3 & 0.1 & 1.1 \\
\hline 2012 & 0.7 & -1.6 & 0.3 \\
\hline \multicolumn{4}{|l|}{ 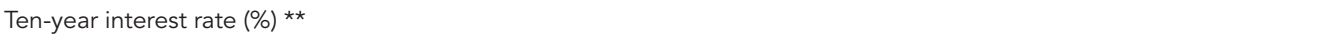 } \\
\hline 12.2008 & 3.05 & 3.86 & 3.36 \\
\hline 12.2009 & 3.14 & 3.81 & 3.60 \\
\hline 12.2010 & 2.91 & 5.38 & 3.34 \\
\hline 12.2011 & 1.93 & 5.53 & 1.81 \\
\hline 07.2012 & 1.24 & 6.79 & 1.47 \\
\hline 12.2012 & 1.30 & 5.34 & 1.60 \\
\hline \multicolumn{4}{|l|}{ Public debt (\% GDP) * } \\
\hline 2008 & 66.8 & 40.2 & 52.3 \\
\hline 2009 & 74.5 & 53.9 & 67.8 \\
\hline 2010 & 82.5 & 61.5 & 79.4 \\
\hline 2011 & 80.5 & 69.3 & 85.0 \\
\hline 2012 & 81.0 & 86.0 & 88.7 \\
\hline Increase in public debt from 2007 to 2011 (\%) & 23.5 & 90.9 & 92.3 \\
\hline \multicolumn{4}{|l|}{ Public deficit/surplus (\% GDP) * } \\
\hline 2008 & -0.1 & -4.5 & -5.1 \\
\hline 2009 & -3.1 & -11.2 & -11.5 \\
\hline 2010 & -4.1 & -9.7 & -10.2 \\
\hline 2011 & -0.8 & -9.4 & -7.8 \\
\hline 2012 & 0.2 & -10.6 & -6.3 \\
\hline Increase in private debt from 2001 to 2007 (\%) * & -8.0 & 62.6 & 30.8 \\
\hline \multicolumn{4}{|l|}{ Unemployment rate ${ }^{\star \star \star \star \star}$} \\
\hline 2008 & 7.3 & 14.9 & 6.5 \\
\hline 2009 & 7.6 & 19.2 & 7.7 \\
\hline 2010 & 6.6 & 20.5 & 7.8 \\
\hline 2011 & 5.6 & 23.2 & 8.3 \\
\hline 2012 & 5.4 & 26.2 & 7.8 \\
\hline
\end{tabular}

GDP: Gross Domestic Product.

* Data from the European Commission. (Eurostat: statistics. http://epp.eurostat.ec.europa.eu/portal/page/portal/statistics/ search_database, accessed 22/Jan/2014);

** Data from the European Central Bank (Statistical data warehouse 2013. http://sdw.ecb.europa.eu, accessed 13/Jan/2013);

$\star \star \star$ Refers to December each year.

the cuts, staff downsizing, and purchase of services, waiting times have increased for elective surgeries 34 .

The CCAA are suffering growing pressure to enforce cuts, but the CCAA have responded differently, depending on their respective governments: five CCAA have filed appeals against RDL $16 / 2012$ on grounds of unconstitutionality and continue to provide treatment to immigrants, with differential enforcement of the legislation 43 .
In the United Kingdom, due to the great importance of the financial sector, the banking crisis of 2008 had serious consequences for the British economy. The UK suffered a recession with a drop in the GDP in 2009, slow growth in the following years, a strong increase in the public debt (92\%), and a public deficit that reached $-11.5 \%$ of GDP in 2009, despite persistently low interest rates (European Central Bank. Statistical data warehouse 2013. http://sdw.ecb.europa.eu, ac- 
Table 6

Impacts of health reforms vis-à-vis the financial crisis (2008-2012) on dimensions of universal care in Germany, Spain, and England.

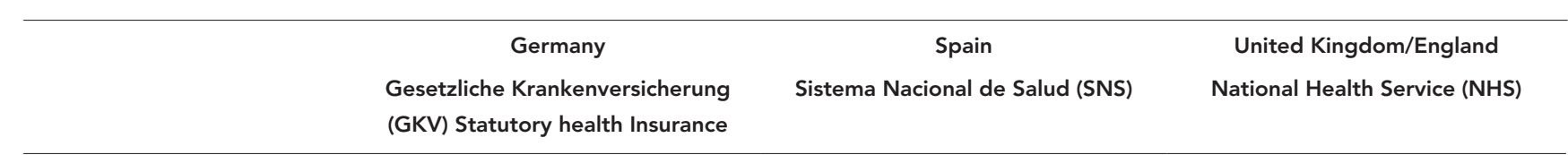

Breadth: variations in

population coverage

Changes in rules for

inclusion

Changes in the proportion of the insured population

Depth: services covered

Changes in package of services - explicit exclusion and cuts in services

Measures for rationing and prioritization of services (formal and informal, implicit and explicit)

Control of entry of new services in package

Increased waiting times

Reduction in supply of health services (staff cuts, reduction in investments)
No

No

No

Implicit in payment systems.

Reinforced action by Joint Federal Commission of the GKV in the definition of whether services will be incorporated into the package

No.

There are no waiting lists for surgeries or delay in specialized consultations regulated: maximum time four weeks.

Merger of Sickness Funds
Changes entitlement to SNS card from citizenship to Social Security membership. For non-members, registration in special agreement via payment of quota.

Excludes undocumented immigrants (150 thousand persons); does not cover individuals $>26$ years without prior participation in the labor market.

Fragments common package of services in SNS: (i) basic: clinical services, without copayment; (ii) supplementary: medicines, orthoses/ prostheses, dietetic products, non-urgent health transportation, with copayments; (iii) accessories. Excludes 417 medicines for minor symptoms.

Implicit in staff and investment cuts.

Increased discretionary power by Ministry of Health in cutting services; expanded control over the entry of new services through creation of the Spanish Network for Health Technology Assessment of the SNS.

Increase in waiting lists for elective surgeries: number of patients on waiting line increased by $43 \%$ from June 2009 to June 2012, and the waiting time increased from 63 to 76 days $(21 \%) 34$

Closing of out-of-hours services and local medical offices in rural areas; closing of surgical centers; reduction of investments by $16.5 \%$ in 2011 and
No

No

No

CCGs may define which services they consider necessary to meet health needs. Some PCTs/CCGs set "priorities".

Due to budget cuts, CCGs will be forced to ration services; already practiced by PCTs, which have excluded services with low costeffectiveness, and have regulated access.

Expands the functions of the National Institute for Health and Care Excellence (NICE): includes social care - assesses whether the procedures are cost-effective and safe and develops guidelines for priorities.

Increase is expected in waiting times (data not available); decrease in user satisfaction.

Reduction in management positions -30 thousand health care professionals displaced.

$35.3 \%$ in 201226 .

(continues) 


\begin{tabular}{|c|c|c|c|}
\hline & $\begin{array}{l}\text { Germany } \\
\text { Gesetzliche Krankenversicherung } \\
\text { (GKV) Statutory health Insurance }\end{array}$ & $\begin{array}{c}\text { Spain } \\
\text { Sistema Nacional de Salud (SNS) }\end{array}$ & $\begin{array}{l}\text { United Kingdom/England } \\
\text { National Health Service (NHS) }\end{array}$ \\
\hline $\begin{array}{l}\text { Privatization of health } \\
\text { services and new } \\
\text { management formats for } \\
\text { public establishments }\end{array}$ & $\begin{array}{l}\text { Merger and sale of some local } \\
\text { hospitals under budget pressure } \\
\text { from national program for } \\
\text { adjustment of public spending. }\end{array}$ & $\begin{array}{l}\text { Plans for outsourcing management } \\
\text { of public hospitals; public-private } \\
\text { partnerships for concession of } \\
\text { services (Madrid, Valencia, Castilla } \\
\text { la Mancha) - strong opposition - } \\
\text { suspension of privatization } 59 \text {. }\end{array}$ & $\begin{array}{l}\text { All hospitals transformed into } \\
\text { Foundation Trusts; CCGs must hire } \\
\text { "any qualified provider" (public or } \\
\text { private); Commissioning support } \\
\text { services to be outsourced. }\end{array}$ \\
\hline \multicolumn{4}{|l|}{$\begin{array}{l}\text { Height: proportion of } \\
\text { expenditures covered by } \\
\text { public resources }\end{array}$} \\
\hline $\begin{array}{l}\text { Proposals to reduce public } \\
\text { expenditures in health }\end{array}$ & $\begin{array}{l}\text { Control GKV contribution rates; } \\
\text { end of parity: freeze employer's } \\
\text { contribution rate. }\end{array}$ & $\begin{array}{l}\text { Reduce public expenditures in } \\
\text { health from } 6.5 \% \text { to } 5.1 \% \text { of GDP by } \\
\text { 2015; per capita spending in SNS } \\
\text { decreased from 1,343 to 1,203 Euros } \\
\text { between } 2010 \text { and } 2012(-10.4 \%) 46 \text {. }\end{array}$ & $\begin{array}{c}\text { Reduce } 20 \text { billion pounds from } 2010 \\
\text { to } 2015 .\end{array}$ \\
\hline \multicolumn{4}{|l|}{$\begin{array}{l}\text { Public expenditures as } \\
\text { share of total health } \\
\text { spending (\%) }\end{array}$} \\
\hline 2007 & 76.4 & 71.9 & 80.2 \\
\hline 2011 & 76.5 & 73.0 & 82.8 \\
\hline \multicolumn{4}{|l|}{$\begin{array}{l}\text { Annual variation in public } \\
\text { expenditures in health (\%) * }\end{array}$} \\
\hline $2008-2009$ & 4.6 & 6.0 & 8.3 \\
\hline $2009-2010$ & 2.3 & -1.2 & -0.7 \\
\hline $2010-2011$ & 0.7 & -4.3 & -1.2 \\
\hline Changes in copayment & $\begin{array}{l}\text { In 2012, abolition of } 10 \text { Euros/quarter } \\
\text { copayment for outpatient medical } \\
\text { consultations. }\end{array}$ & $\begin{array}{l}\text { Increase in rates and expansion of } \\
\text { services subject to copayment for } \\
\text { health transportation, ortheses/ } \\
\text { prostheses, and dietetic products; } \\
\text { copayment of medicines for } \\
\text { pensioners. }\end{array}$ & $\begin{array}{l}\text { Implicit: providers offer NHS } \\
\text { patients the "option" of direct } \\
\text { private payment (self-funding) } \\
\text { of procedures not approved by } \\
\text { PCTs or with long waiting times } \\
\text { (in vitro fertilization, bone mineral } \\
\text { densitometry) } 58 \text {. }\end{array}$ \\
\hline
\end{tabular}

CCAA: Autonomous Communities; CCGs: clinical commissioning groups; PCTs: primary care trust.

* Organisation for Economic Co-operation and Development. OECD Health Statistics 2013. http://www.oecd.org/els/health-systems/oecdhealthdata.htm (accessed 15/Jan/2014).

Source: prepared by the authors, based on The National Archive 33; Congreso de los Diputados 41; and Reiners \& Müller 65.

cessed 13/Jan/2013. European Commission. Eurostat: statistics. http://epp.eurostat.ec.europa. eu/portal/page/portal/statistics/search_data base, accessed 22/Jan/2014) (Table 5). The economy's heavy dependency on the financial sector and the private indebtedness during the crisis forced the British government to deal with the dual challenge of dwindling revenues from the financial sector and the simultaneous need to inject public resources into this sector to avoid a collapse in the banking industry 11 . However, the British austerity program did not result from an imposition by the European Union. The United
Kingdom did not introduce the Euro, and to defend its financial elites, it refused to participate in the fiscal pact of 2012, which included guidelines for regulating the financial system 39 .

In England, with the new UK ConservativeLiberal coalition government, 2010 witnessed an important reform in the NHS, regulated in 2012 in the Health and Social Care Act 2012 33, which established a budget cut policy in NHS-England (20 billion pounds in five years) and stepped up previous trends towards privatization of services and the introduction of greater competition within the NHS, with the reorganization 
of relations between financing/purchasing and delivery and expanded roles for the regulatory agencies 32,49,50. The CCGs were created as local organizations of GP clinics, replacing the PCTs since April 2013 in hiring specialized and hospital services for their enrolled patients (abandoning territorial accountability 51 and taking over management of $70 \%$ of NHS expenditures). To encourage competition, the CCGs are mandated to purchase services from "any qualified provider", which includes the public hospitals of the NHS (all of which to be turned into Foundation Trusts) and private providers. The CCGs are also expected to present referred patients with different options for providers 33 , a measure intended to incentivize private supply, which still has a limited presence in the NHS. The CCGs are intended as small administrative structures and hiring Commissioning Support Services (CSS) for the commissioning tasks 52,53 . The aim is to cut administrative expenditures in the NHS by $45 \%$, with an estimated 30 thousand displaced NHS employees 32 (Table 6).

The CCGs will have greater autonomy and will be regulated by NHS-England, an independent organization vis-à-vis the Department of Health, a move that has been interpreted as eliminating the responsibility of the Secretary of State for Health in guaranteeing care 54. The CCGs should guarantee health care delivery but are not responsible for the population's health in a given geographic area, except for urgent and emergency care. According to Pollock \& Price 55, government's duty to provide comprehensive care has been abolished, since according to the new law, government only has the duty to promote comprehensive care, not to guarantee it.

Germany, with a production model based on high-tech development, a highly skilled workforce, and high productivity, was benefited by the introduction of the Euro 2, which facilitated exportation within the region. In an advantageous positon due to growing German trade surpluses with the other European countries and extremely low interest rates, Germany resumed positive growth in 2010, reduced unemployment (Table 5 ), and received investments, and the social insurance schemes showed surpluses in 2012 due to rising employment 38 .

In Germany, the financial crisis was not accompanied by new containment measures or a structural health reform, but the crisis did serve as the catalyst and legitimation for the intensification of social cuts and the commodification of health by the Conservative-Liberal coalition 5 . The country enacted a series of laws on financing, pharmaceutical care, and regulation and improvement of the services supply in rural areas 28

The 2009 recession led to forecasts of deficits in the GKV, and initially to compensate for revenue losses resulting from the crisis, the country established an additional transfer of fiscal resources to the GKV Health Fund (created in 2007). In 2010, the contribution rate in the GKV was increased to $15.5 \%$ and the parity contribution was revoked: employers' contribution was fixed at $7.3 \%$ and workers' contribution was increased to $8.2 \%$ of wages. The limit was also abolished on charging an additional tax (a per capita amount bearing no relationship to wages and paid directly by members to the Sickness Fund in case the latter was unable to cover its expenses with the resources from the GKV Fund), thereby reducing solidarity in financing 56 .

Germany also passed an important law in 2010 to restructure the pharmaceutical market, establishing a set of rules for price controls and cuts for medicines and rigorous standards for systematic evaluation of the benefits of new drugs by the GKV Joint Federal Commission, expanding its functions 28,56 .

\section{Immediate and potential repercussions for universal coverage}

The reforms in the three countries impact the three dimensions of universal coverage to different degrees (Table 6). The first dimension, "breadth of population coverage by the public system" is affected in Spain by changes in the rules for inclusion, which will result in reductions in the proportion of the population insured in the short and long term, with the exclusion of undocumented immigrants and residents not enrolled in Social Security. However, no changes have been observed so far in the indicators for population coverage, since the number of undocumented immigrants is relatively small, and some Autonomous Communities and services have resisted enforcing the restrictions.

In the three countries, coverage by the public system has remained at the previous levels, and there has been no increase in coverage by private insurance. The proportion of the population with duplicate coverage in Spain and England has not changed, and in Germany the population covered by substitute private insurance has remained at the same level (Table 3) 29.

The dimension of universal coverage "depth of the services package" is under stress and is suffering various types of restrictions in the three countries. Spain is experiencing changes in the package of services, with the explicit exclusion of 
certain services. In England, the CCGs will be able to define the services they consider necessary 54 . In the three countries, implicit rationing measures with prioritization of services tend to result from budget cuts. There has been stricter control on the inclusion of new services in the package, strengthening the regulatory bodies' role (Table 6). The increase in waiting times for elective surgeries is an immediate effect of the cuts in Spain and those planned in England. Spain is suffering a reduction in the supply of health services due to cuts in staff and investments.

New management formats in public establishments, public-private partnerships for investments, privatization, and outsourcing of hospital administration are trends in all three countries that can influence the availability of services, given their commercial orientation. In England, all public hospitals are to be turned into Foundation Trusts with greater autonomy and the possibility of raising private funds, and the CCGs will be required to hire any provider, thus pointing to greater private sector participation in health care delivery. Even so, in Spain, the Conservative government in Madrid gave up on its plan to privatize public hospitals due to the widespread social mobilization of the marea blanca movement in defense of public hospitals and the five-week health workers' strike 57 .

The third dimension of universal coverage, "height of coverage by public financing" has been affected by budget cuts and increases in copayments, although no immediate impact has been seen in the proportion of health expenditures covered publicly, which were slightly higher in 2011 than in 2007 and maintained their share of GDP (Tables 2 and 6). The legislation set restrictions. Beginning in 2009, the trend was towards decreasing public expenditures in Spain and the UK and a slowdown in Germany, mirroring the overall trend in European countries towards reducing public health expenditures since the financial crisis 7,8 .

Increases in copayments shift the responsibility for financing from the state to families. Following the trend in other European countries 6, copayments were expanded explicitly in Spain and implicitly in England, since public hospitals transformed into autonomous organizations have started offering NHS patients the "option" of direct private payment for certain services 58 . In Germany, on the contrary, given the GKV surplus, copayment was abolished from outpatient care due to pressure by physician specialists who were constituents of the Liberal Party, part of the Conservative government coalition ${ }^{38}$.

\section{Final remarks}

The recent international financial crisis heightened the economic pressures on national health systems and was used as an opportunity by conservative governments to extend restrictive measures, expand market space and competition, and reduce state intervention 5,39 .

Recent policies in the face of the financial crisis follow the previous strategies of "marketoriented reforms" and extend regulated competition, with separation of roles between financers/purchasers and providers of services in the national health systems, besides mechanisms to expand competition between insurance organizations in social insurance. There has been an expansion of management measures inspired by the "New Public Management", with new management models in public services and the relationship between providers and purchases regulated by contracts.

Responses to the crisis in the three cases had common objectives of containing public health expenditures and austerity policies to control the public deficit, however with different measures. Spain, the country of the three most heavily affected by the crisis, has suffered more drastic cuts with an emphasis on increases in copayment, exclusion from coverage, and cuts in staff expenditures. The English reform is the deepest, with extensive reorganization of the NHS and of the relations between financers and providers with a reduction in management roles and administrative personnel and opening of the "internal market" to private providers, with an increase in competition and commercialization in the NHS. Financing remains public, but with a trend towards privatization in various components of the NHS: encouragement for private use of hospital services, delivery of GP services by private companies, changes in the management and ownership models in NHS hospitals, and outsourcing of funds management with the creation of the CCGs. Decisions on allocation of the majority of NHS resources will be made by CSS outsourced, and no longer by NHS agencies as in the case of the PCTs. Germany, better positioned in the crisis, with low unemployment, showed a surplus in its Social Health Insurance and reinforced its policies to stabilize the contribution rates. The country froze the employers' contribution, shifting the responsibility for future increases to employees, allowing additional taxes stipulated by the Sickness Funds in case the latter fail to cover their expenditures with resources from the GKV Fund, forcing competition between Sickness Funds and a reduction in expenditures. 
The degree of impact of restrictive measures differs between the three countries, due to their diverse health protection models, institutional frameworks, and health sector stakeholder constellations, besides their very different positions in the European financial crisis and economy. The "breadth" of the insured population has only been explicitly affected in Spain. The "depth" of the package of services covered by their health systems has been affected indirectly in the three countries, with greater control over the incorporation of new procedures and restrictions on delivery. Per capita public expenditures have decreased in Spain and England, affecting the "height" of universal coverage.

Nevertheless, these changes have only had a marginal effect on universal coverage thus far: public schemes cover the vast majority of the population, the package of services insured by the system remains deep, and in the three countries more than $74 \%$ of health expenditures remain public. In the face of the crisis, the European countries in general have not made important changes in the package of legally insured benefits, and reductions in population coverage have mostly been marginal 6 . However, there has been a stagnation or reduction in public health expenditures which, if it persists, could have harmful consequences for universal coverage in the medium term.
This is an open process. The financial crisis has placed serious pressures on the European welfare states and national health systems, but analyses of the repercussions of previous experiences with conservative reforms in the 1980s and 90s suggest non-linear processes with both backward and forward trends. Pro-market rhetoric has been more intense than its implementation in practice, and the principle of solidarity and the health systems' public nature have not been seriously shaken $35,37,59,60,61$.

Meanwhile, crises can also engender positive consequences and new solutions. Economic crisis situations highlight the importance of social policies to mitigate their adverse effects, and citizens can rally to defend such policies 62 . The intensity of repercussions on universal coverage in the medium and long term will be conditioned by the action of social stakeholders and the nature of the crisis (whether situational or structural) as a crisis of democratic capitalism characterizing Western Europe in the latter half of the $20^{\text {th }}$ century 1 .

This study of selected national cases revealed a diversity of situations in the respective health systems in the face of the financial crisis, while contributing to the contemporary debate on universal coverage ${ }^{63}$. Nevertheless, this was a situational analysis limited to examining the recent literature and general data, which does not allow identifying the consequences for specific social groups or geographic and social inequalities. Unveiling the long-term trends requires further follow-up and new studies.

\section{Resumen}

El artículo analiza las tendencias de reformas de salud contemporáneas -dentro del contexto de la crisis económica (2008)- en países europeos con sistemas universales de salud (modelos bismarckiano y beveridgiano) $y$ discute las implicaciones para la universalidad. Se analizan las reformas de salud en España, Alemania y Reino Unido. Para la descripción de los sistemas de salud se utiliza una matriz comparativa de la intervención del Estado en la financiación, regulación, organización y prestación de servicios. Se examinan los efectos de las reformas sobre la universalidad en base a tres dimensiones: amplitud de la cobertura a la po- blación; composición de la cesta de servicios; y nivel de cobertura con fondos públicos. La diversidad de modelos de protección en salud, instituciones implicadas, constelaciones de actores y la posición de esos países en la economía europea han condicionado el impacto de las políticas restrictivas en cada uno de ellos. Estas últimas afectaron a la universalidad en sus tres dimensiones, con diferente intensidad, y profundizaron políticas anteriores de competencia regulada y comercialización.

Acceso Universal a Servicios de Salud; Reforma de la Atención de Salud; Política de Salud 


\section{Contributors}

L. Giovanella and K. Stegmüller participated in the article's conceptualization, analysis and interpretation, and writing and critical revision of the manuscript.

\section{Acknowledgments}

The authors wish to thank CAPES for the senior overseas research grant (BEX 3831/11-6) and Mariana Konder for her support in the final revision.

\section{References}

1. Streeck W. Die Krisen des demokratischen Kapitalismus. Lettre International 2011; 95:7-13.

2. Lehndorff S. Ein Triumph gescheiterter Ideen. Warum Europa tief in der Krise steckt. Hamburg: VSA Verlag; 2012.

3. Observatório Português dos Sistemas de Saúde. Um país em sofrimento. Lisboa: Observatório Português dos Sistemas de Saúde; 2012.

4. Wahrig L, Vallina IG. The effect of the economic and financial crisis on government revenue and expenditure. Eurostat Statistics in Focus 2011; 45:1-12.

5. Heise A, Lierse H. Haushaltkonsolidierung und das Europäische Sozialmodell. Auswirkungen der europäischen Sparprogramme auf die Sozialsysteme. Berlin: Friedrich Ebert Stiftung; 2011.

6. Mladovsky P, Srivastava D, Cylus J, Karanikolos M, Evetovits T, Thomson S, McKee M. Health policy in the financial crisis. Eurohealth 2012; 18:3-6.

7. Morgan D, Astolfi R. Health spending growth at zero: which countries, which sectors are most affected? Paris: OECD Publishing; 2013. (OECD Health Working Papers, 60).

8. Organisation for Economic Co-operation and Development. Health at a glance: Europe 2012. Paris: OECD Publishing; 2012.

9. Kondilis AND, Giannakopoulos S, Gavana M, Ierodiakonou I, Waitzkin H, Benos A. Economic crisis, restrictive policies, and the population's health and health care: the Greek case. Am J Public Health 2013; 103:973-9.
10. Gili M, Roca M, Basu S, McKee M, Stuckler D. The mental health risks of economic crisis in Spain: evidence from primary care centres, 2006 and 2010. Eur J Public Health 2013; 23:103-8.

11. McKee M, Karanikolos M, Belcher P, Stuckler D. Austerity: a failed experiment on the people of Europe. Clin Med 2012; 12:346-50.

12. Titmuss RM. What is social policy? In: Abel-Smith B, Titmuss K, editors. Social Policy. London: George Allen and Unwin; 1974. p. 24-32.

13. Esping-Andersen G. The Three Worlds of Welfare Capitalism. Cambridge: Polity Press; 1990.

14. Meny I, Thoenig JC. Las políticas públicas. Barcelona: Ariel Ciencia Política; 1992.

15. Oliver A. The folly of cross-country ranking exercises. Health Econ Policy Law 2012; 7:15-7.

16. Dixon A, Poteliakhoff E. Back to the future: 10 years of European health reforms. Health Econ Policy Law 2012; 7:1-10.

17. Sartori G, Morlino L. La comparación en las ciencias sociales. Madrid: Alianza Editorial; 1994.

18. Marmor TR, Freeman R, Okma KGH. Comparative studies and politics of modern medical care. London: Yale Press University; 2009.

19. Immergut E. Health Politics: interest and institutions in Western Europe. New York: Cambridge University Press; 1992.

20. World Health Organization. The World Health Report 2008. Primary health care: now more than ever. Geneva: World Health Organization; 2008. 
21. Burau V, Fenton L. How healthcare states matter: comparing the introduction of clinical standards in Britain and Germany. J Health Organ Manag 2009; 23:289-303.

22. Arts W, Gelissen J. Three worlds of welfare capitalism or more? A state-of-the-art report. J Eur Soc Policy 2002; 12:137-58.

23. Stegmüller K. Wettbewerb im Gesundheitswesen: Konzeptionen zur "dritten reformstufe" der Gesetzlichen Krankenversicherung. Frankfurt: Verlag Akad Schriften; 1996.

24. Boyle S. United Kingdom (England): health system review. Health Syst Transit 2011; 13:1-483.

25. Freire JM. La atención primaria de salud y los hospitales en el Sistema Nacional de Salud: importancia y retos de la universalización y la equidad en el aseguramiento. In: Navarro López V, editor. El estado de bienestar en España. Madrid: Tecnos; 2004. p. 239-91.

26. Repullo-Labrador JR. La sostenibilidad de las prestaciones sanitarias públicas. In: Presno Linera MA, editor. Crisis económica y atención a las personas y grupos vulnerables. Oviedo: Universidad de Oviedo; 2012. p. 132-62.

27. Lopez-Casasnovas G, Costa-Font J, Planas I. Diversity and regional inequalities in the Spanish "system of health care services". Health Economics 2005; 14 Suppl 1:S221-35.

28. Bundesministerium für Gesundheit. Daten des Gesundheitswesens 2012. Berlin: Bundesministerium für Gesundheit; 2012.

29. García-Armesto S, Abadía-Taira MB, Durán A, Hernández-Quevedo C, Bernal-Delgado E. España: análisis del sistema sanitario. Sistemas Sanitarios en Transición 2011; 12:1-269.

30. Helderman JK, Bevan G, France G. The rise of the regulatory state in health care: a comparative analysis of the Netherlands, England and Italy. Health Econ Policy Law 2012; 7:103-24.

31. Gerlinger T. Competitive transformation and state regulation in social health insurance countries: Germany, Switzerland, and the Netherlands compared. In: Dingeldey I, Rothgang H, editor. Governance of welfare state reform: a cross national and cross sectoral comparison of policy and politics. Cheltenham: Edward Elgar; 2009. p. 145-75.

32. Baker MR, Ham C. Making sense of the new NHS White Paper. Abingdon: Radcliffe Publishing Ltd.; 1998.

33. The National Archives. Health and social care act 2012. http://www.legislation.gov.uk/ukpga/2012/ 7/contents/enacted (accessed on 02/Aug/2012).

34. Ministerio de Sanidad, Servicios Sociales e Igualdad. Estadística de centros sanitarios de atención especializada. Resultados provisionales, año 2010. Madrid: Ministerio de Sanidad, Servicios Sociales e Igualdad; 2011.

35. Altenstetter C, Björkman JM. Health policy reform, national variation and globalization. London: MacMillan Press; 1997.

36. Rico A, Costa-Font J. Power rather than path dependency? The dynamics of institutional change under health care federalism. J Health Polit Policy Law 2005; 30:231-51.
37. Toth F. Healthcare policies over the last 20 years: reforms and counter-reforms. Health Policy 2010; 95:82-9.

38. Schuldenkrise: Nervenkampf um den Euro. http:// www.spiegel.de/politik/deutschland/mario-mon ti-trifft-kanzlerin-merkel-zum-euro-krisengipfela-839978.html (accessed on 22/Jun/2012).

39. Taylor-Gooby P, Stoker G. The coalition programme: a new vision for Britain or politics as usual? Polit Q 2011; 82:4-15.

40. Banyuls J, Recio B. Der Albtraum des Mediterranen Neoliberalismus. Spanien nach dem Scheitern des „dritten Weges. In: Lehndorff S, editor. Ein Triumph gescheiterter Ideen. Warum Europa tief in der Krise steckt Zehn Länder-Fallstudien. Hamburg: VSA Verlag; 2012. p. 207-25.

41. Navarro V. Spain is experiencing a period of intense social crisis. http://www.social-europe. eu/2012/11/spain-is-experiencing-a-period-of-in tense-social-crisis/?utm_source=feedburner\&utm medium $=$ feed\&utm_campaign=Feed $\% 3 \mathrm{~A}+$ social europe\%2FwmyH+\%28Social+Europe+Journal\%29 (accessed on 12/Nov/2012).

42. Congreso de los Diputados. Real Decreto Ley no 16/2012, de 20 de abril de medidas urgentes para garantizar la sostenibilidad del Sistema Nacional de Salud y mejorar la calidad y seguridad de sus prestaciones. Boletín Oficial del Estado 2012; 24 abr.

43. Rico A, Blakey E. El impacto de la crisis en sanidad: recortes estructurales asimétricos con altos costes diferidos. In: Fundación Encuentro, editor. Informe España 2012. Madrid: Fundación Encuentro; 2011. p. 173-233.

44. Federación de Asociaciones para la Defensa de la Sanidad Pública. Comienza la contrarreforma sanitária: análisis del RD-Ley 16/2012. Madrid: Federación de Asociaciones para la Defensa de la Sanidad Pública; 2012.

45. Freire JM. Notas de urgencia sobre el Real Decreto Ley del copago y los recortes sanitarios (RDL 16/2012). http://www.actasanitaria.com/notasde-urgencias-sobre-el-real-decreto-ley-del-copa go-y-los-recortes-sanitarios-rdl-162012/ (accessed on 30/May/2012).

46. Ärzteblatt D. Fünf Fragen zur Zahl der Arztkontakte an Dominik von Stillfried. Deutsches Ärzteblatt. http://www.aerzteblatt.de/nachrichten/49601/ Fuenf-Fragen-zur-Zahl-der-Arztkontakte-anDominik-von-Stillfried (accessed 22/Mar/2012).

47. Federación de Asociaciones para la Defensa de la Sanidad Pública. Informe sobre los recortes sanitarios en las Comunidades Autónomas. Madrid: Federación de Asociaciones para la Defensa de la Sanidad Pública; 2012.

48 Sánchez-Bayle M. Evolución de la financiación sanitaria entre 1981-2010. In: Palomo L, editor Treinta años del Sistema Sanitario Español (19812011). Madrid: Federación de Asociaciones para la Defensa de la Sanidad Pública; 2011.

49. Hunter DJ. Change of government: one more big bang health care reform in England's National Health Service. Int J Health Serv. 2011;41(1):159-74. 
50. Roland M, Rosen R. English NHS embarks on controversial and risky market-style reforms in health care. N Engl J Med 2011; 364:1360-6.

51. Whitehead M, Hanratty B, Popay J. NHS reform: untried remedies for misdiagnosed problems? Lancet 2010; 376:1373-5.

52. Reynolds L, McKee M. GP commissioning and the NHS reforms: what lies behind the hard shell? J R Soc Med 2012; 105:7-10.

53. Reynolds L, McKee M. "Any qualified provider" in NHS reforms: but who will qualify? Lancet 2012; 379:1083-4.

54. Pollock A, Price D. How the secretary of state for health proposes to abolish the NHS in England. BMJ 2011; 342:d1695.

55. Pollock AM, Price D, Roderick P, Treuherz T, McCoy D, McKee M, et al. How the Health and Social Care Bill 2011 would end entitlement to comprehensive health care in England. Lancet 2012; 379:387-9.

56. Simon M. Von der Koalitionsvereinbarung bis Ende 2010: Eine Zwischenbilanz Schwarz-gelber Gesundheitspolitik. Jahrbuch für kritische Medizin und Gesundheitswissenschaft 2012; 47:9-28.

57. Marcos J, Sevillano EG. Madrid da marcha atrás a la privatización sanitaria tras el último revés judicial. http://ccaa.elpais.com/ccaa/2014/01/27/ma drid/1390839012_137715.html (accessed on 27/ Jan/2014).
58. O'Dowd A. The "self funding" NHS patient: thin end of the wedge? BMJ 2012; 345:e5128.

59. Conill E. Sistemas comparados de saúde. In: Akerman M, Campos GWS, Carvalho YM, Drumond Junior M, Minayo MCS et al. organizadores. Tratado de saúde coletiva. 2a Ed. São Paulo: Editora Hucitec; 2012. p. 591-659.

60. Maarse H, Paulus A. Has solidarity survived? A comparative analysis of the effect of social health insurance reform in four European countries. J Health Polit Policy Law 2003; 28:585-614.

61. Almeida CM. Reformas de sistemas de saúde: tendências internacionais, modelos e resultados. In: Giovanella L, Escorel S, Lobato LVC, Noronha JC, Carvalho AI. Políticas e sistema de saúde no Brasil. Rio de Janeiro: Editora Fiocruz; 2008. p. 871-922.

62. Hemerijck A. When Changing welfare states and the Eurocrisis meet. Sociologica 2012; (1):1-49.

63. Noronha JC. Cobertura universal de saúde: como misturar conceitos, confundir objetivos, abandonar princípios. Cad Saúde Pública 2013; 29:847-9.

64. Organisation for Economic Co-operation and Development. Health at a glance 2013: OECD indicators. Paris: OECD Publishing; 2013.

65. Reiners H, Müller O. Die Reformfibel: Handbuch der Gesundheitsreformen. Berlin: KomPart-Verlag; 2012.

Submitted on $11 / \mathrm{Feb} / 2014$

Final version resubmitted on 22/Jun/2014

Approved on 28/Jul/2014 